Горшкова Олена Георгіївна, молодший науковий співробітник (аспірант) Біотехнологічного науковонавчального центру, Одеський національній університет ім. І. І. Мечникова, вул. Дворянська, 2, м. Одеса, Україна, 65082

E-mail: elena-good@bk.ru

Бєлясва Тамара Олексіївна, науковий співробітник Біотехнологічного науково-навчального центру, кафедра мікробіології, вірусології та біотехнології, Одеський національній університет ім. І. І. Мечникова, вул. Дворянська, 2, м. Одеса, Україна, 65082

Конуп Ігор Петрович, науковий співробітник Біотехнологічного науково-навчального центру, кафедра мікробіології, вірусології та біотехнології, Одеський національній університет ім. І. І. Мечникова, вул. Дворянська, 2, м. Одеса, Україна, 65082

Дімова Марія Іванівна, кафедра мікробіології, вірусології та біотехнології, Одеський національний університет ім. І. І. Мечникова, вул. Дворянська, 2, м. Одеса, Україна, 65082

E-mail: dimova.92@mail.ru

УДК 633. 111: 57. 085.2(043.3)

DOI: $10.15587 / 2313-8416.2014 .31733$

\title{
ДОСЛІДЖЕННЯ АНДРОГЕНЕЗУ IN VITRО В КУЛЬТУРІ ПИЛЯКІВ СОРТІВ ТА РЕЦИПРОКНИХ ГІБРИДІВ ПШЕНИЦІ М'ЯКОЇ ОЗИМОЇ
}

\author{
(C) І. С. Замбріборщ, О. Л. Шестопал
}

Провели тестування гаплопродукиійної здатності в культурі in vitro пиляків м'якої озимої пшениці. У гібридів $F_{1}$ виявлено різний характер наслідування показників «формування новоутворень» та «регенерації зелених рослин»: ефекти гетерозису та депресії, проміжний характер наслідування або прояв ознак на рівні одного з батьків. В культурі пиляків озимої пшениці отримано 283 зелених рослинирегенеранта

Ключові слова: м'яка пшеничя, культура пиляків іп vitro, подвійні гаплоїди, регенерачія

Testing of haploprodution ability in vitro anther culture of bread winter wheat was studied. The different nature of indicator inheritance of "forming of tumors" and "regeneration of green plants" for F1 hybrids were detected: effects of heterosis and depression, intermediate nature, and the inheritance of signs at the level of the parents. The 283 green plant-regenerants were obtained by anther culture of winter wheat

Keywords: bread wheat, anther culture in vitro, double haploids, regeneration

\section{1. Вступ}

Сьогодні широкий розвиток i практичне використання стосовно різних сільськогосподарських культур здобули біотехнології на рівні гаплоїдних клітин. Для злаків, зокрема для пшениці, для отримання дигаплоїдних рослин широко застосовується біотехнологія, заснована на явищі андрогенезу у системі культивування пиляків in vitro [1-4]. Ідея розробки цієї технології полягає у збагаченні сучасної селекції рослин допоміжними методами одержання гомозиготних ліній з гібридних популяцій 3 метою прискореного створення лінійних, достатньо продуктивних й високо адаптивних сортів економічно цінних злаків [5].

\section{2. Постановка проблеми}

Для ефективного отримання лінійного матеріалу озимої пшениці з подальшим залученням останнього у селекційні програми актуальною є проблема виявлення найбільш чутливих до андрогенезу in vitro форм серед наданих селекціонером. Тому мета даного дослідження полягала у тестуванні гаплопродукційної здатності 4 батьківські сортів та отриманих на їхній основі 12 популяцій реципрокних гібридів $\mathrm{F}_{1}$ пшениці м'якої озимої.

\section{3. Літературний огляд}

Про явище «андрогенезу in vitro» у м'якої пшениці вперше за результатами трьох незалежних досліджень у 1973 році повідомили Ouyang L. W., Picard E., J. De Buyser та Wang C. С. Перші рослини подвоєних гаплоїдів у культурі пиляків пшениці було отримано на початку 70-х років. Поступово метод удосконалювався, підвищувалась його ефективність. У роботах різних авторів були розроблені й підібрані живильні середовища для культивування пиляків i визначено чинники, що впливають на проявлення здатності до андрогенезу рослин у культурі in vitro [6]. Це дозволило одержувати нові сорти пшениці 3 подвоєних гаплоїдів.

Проте, у теперішній час, за потенційно високої ефективності цієї біотехнологічної системи андрогенезу in vitro, у порівнянні 3 традиційними методами селекції, які використовуються для одержання лінійного матеріалу пшениці, результативність методу культури пиляків поки що недостатня. Висока генотипоспецифічність м'якої пшениці за чутливістю до андрогенезу in vitro обумовлює низький вихід подвоєних гаплоїдів, особливо, у роботі з озимими формами [1, 3, 4]. Виходячи 3 цього, вдосконалення окремих етапів цієї перспективної біотехнології, що ведуть до регенерації 
рослин, представляє науковий і практичний інтерес. При цьому, особливого значення набуває пошук шляхів підвищення рівня регенерації зелених рослин.

\section{4. Матеріали та методи дослідження}

У роботу 3 тестування гаплопродукційної здатності пшениці озимої м'якої залучено 4 батьківські сорти (Щедрість, Гарантія, Традиція та Мудрість), які ніколи не залучались у подібні дослідження; отримані на їхній основі 12 популяцій реципрокних гібридів $F_{1}$.

Рослини вирощували на польових ділянках відділу селекції та насінництва пшениці СГІ-НЦНС. Пагони 3 пиляками зрізали 3 донорних рослин, коли мікроспори знаходились на стадії від ранньої до пізньої вакуолізації. Попередню обробку зрізаних пагонів проводили у водному розчині АБК (0,5 мг/л) протягом 3-5 діб при $+2-+4{ }^{\circ} \mathrm{C}$ у темряві. Колосся поверхнево стерилізували насиченим розчином гіпохлориту кальцію за прийнятою методикою. Ізольовані пиляки висаджували на індукційне живильне середовище 190-2 [7] у модифікації [8]. Висаджені пиляки культивували перші 3 доби у темряві за температури $+30^{\circ} \mathrm{C}$, далі - при $+24{ }^{\circ} \mathrm{C}$ до появи новоутворень. Сформовані макроструктури пересаджували на середовищі MS 3 додаванням
0,2 мг/л 2,4-Д, 0,5 мг/л кінетину, 200 мг/л проліну, 200 мг/л глютаміну, 30 г/л цукрози та 2,9 г/л гелриту. Культивували у темряві 3-4 тижня до появи центрів регенерації; далі - пересаджували експланти на живильне середовище MS 3 половинною концентрацією солей без гормонів та культивували за умов 16-годинного фотоперіоду, інтенсивності освітлення - 10 тис. люкс, при температурі $+24{ }^{\circ} \mathrm{C}$ до формування рослин. Зелені рослини пересаджували на свіже безгормональне живильне середовище MS та яровизували (за температури $+2-4{ }^{\circ} \mathrm{C}, 16-$-годинному фотоперіоді, інтенсивності освітлення 3000-3500 люкс).

Отриманні рослини-регенеранти зростають в умовах штучного клімату.

\section{5. Результати досліджень}

Результати тестування гаплопродукційної здатності в культурі пиляків in vitro 12 гібридних популяції $\mathrm{F}_{1}$ та 4 батьківських сортів пшениці озимої м'якої наведені в табл. 1. Слід зазначити, що дані сорти ніколи не тестувалися щодо їх гаплопродукційної здатності. Показано, що за даних умов експерименту усі досліджені генотипи виявились чутливими до андрогенезу in vitro (табл. 1).

Таблиця 1

Ефективність гаплопродукційного процесу в культурі пиляків in vitro сортів та гібридів пшениці озимої м'якої

\begin{tabular}{|l|c|c|c|c|}
\hline \multirow{2}{*}{ Генотип } & Новоутворення,\% від & \multicolumn{3}{|c|}{ Регенерація, \% від висаджених пиляків } \\
\cline { 3 - 5 } & висаджених пиляків & зелені & альбіно & різогенез \\
\hline Щедрість & $8,85 \pm 0,79$ & $3,23 \pm 0,49$ & $0,54 \pm 0,20$ & $2,62 \pm 0,44$ \\
\hline Традиція & $4,24 \pm 0,58$ & $1,06 \pm 0,29$ & $0,25 \pm 0,14$ & $1,06 \pm 0,29$ \\
\hline Мудрість & $3,15 \pm 0,42$ & $0,97 \pm 0,23$ & $0,46 \pm 0,16$ & $0,74 \pm 0,21$ \\
\hline Гарантія & $1,45 \pm 0,36$ & $0,09 \pm 0,09$ & $0,09 \pm 0,09$ & $0,73 \pm 0,26$ \\
\hline $\mathrm{F}_{1}$ Щедрість х Традиція & $5,46 \pm 0,67$ & $1,14 \pm 0,32$ & $0,26 \pm 0,15$ & $1,67 \pm 0,38$ \\
\hline $\mathrm{F}_{1}$ Традиція х Щедрість & $14,73 \pm 1,01$ & $4,59 \pm 0,59$ & $1,21 \pm 0,31$ & $2,25 \pm 0,42$ \\
\hline $\mathrm{F}_{1}$ Щедрість х Мудрість & $3,10 \pm 0,53$ & $0,19 \pm 0,13$ & $0,28 \pm 0,16$ & $0,47 \pm 0,21$ \\
\hline $\mathrm{F}_{1}$ Мудрість х Щедрість & $7,32 \pm 0,87$ & $1,22 \pm 0,37$ & $0,44 \pm 0,22$ & $2,44 \pm 0,51$ \\
\hline $\mathrm{F}_{1}$ Щедрість х Гарантія & $6,31 \pm 0,64$ & $1,37 \pm 0,30$ & $0,41 \pm 0,17$ & $0,62 \pm 0,21$ \\
\hline $\mathrm{F}_{1}$ Гарантія х Щедрість & $7,05 \pm 0,67$ & $1,80 \pm 0,35$ & $0,69 \pm 0,22$ & $1,45 \pm 0,31$ \\
\hline $\mathrm{F}_{1}$ Гарантія х Традиція & $2,46 \pm 0,38$ & 0 & $0,43 \pm 0,16$ & $0,49 \pm 0,17$ \\
\hline $\mathrm{F}_{1}$ Традиція х Гарантія & $3,78 \pm 0,57$ & $0,99 \pm 0,30$ & $0,36 \pm 0,18$ & $0,72 \pm 0,25$ \\
\hline $\mathrm{F}_{1}$ Гарантія х Мудрість & $6,05 \pm 0,64$ & $0,36 \pm 0,16$ & $0,71 \pm 0,22$ & $2,13 \pm 0,39$ \\
\hline $\mathrm{F}_{1}$ Мудрість х Гарантія & $5,26 \pm 0,67$ & $0,54 \pm 0,22$ & $0,91 \pm 0,29$ & $2,27 \pm 0,45$ \\
\hline $\mathrm{F}_{1}$ Мудрість х Традиція & $3,91 \pm 0,56$ & $1,10 \pm 0,30$ & $0,08 \pm 0,08$ & $1,19 \pm 0,32$ \\
\hline $\mathrm{F}_{1}$ Традиція х Мудрість & $3,35 \pm 0,59$ & $0,11 \pm 0,11$ & $0,86 \pm 0,30$ & $0,97 \pm 0,32$ \\
\hline НСР 0.05 & 2,23 & 1,05 & 0,7 & 0,3 \\
\hline
\end{tabular}

Показано, що серед сортів найвищими показниками гаплопродукційної здатності (формування новоутворень та зелених рослин-регенерантів) характеризувався сорт Щедрість $(8,85 \pm 0,79$ шт. та $3,23 \pm 0,49$ шт. на 100 висаджених пиляків відповідно). Середній рівень відгуку в культурі пиляків in vitro продемонстрували сорти Мудрість та Традиція. Значно нижчі показники, що характеризують ефективність андрогенезу, виявили у сорту Гарантія -

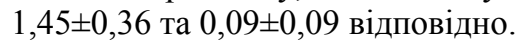

Вкрай цінними для подальшої роботи 3 отримання подвоєних гаплоїдів пшениці є отримані дані щодо чутливості до умов андрогенезу реципрокних гібридів першого покоління. Саме 3 популяції гібриди $\mathrm{F}_{1}$ можливо відразу за один цикл схрещування шляхом культури пиляків одержувати гомозиготний матеріал для подальшої селекційної роботи. За рівнем індукції новоутворень у гібридів виявлені різні типи прояву даної ознаки. Так, у трьох 3 них (Традиція х Щедрість, Мудрість х Гарантія і Гарантія х Мудрість) виявили гетерозисний ефект (табл. 1, рис. 1), тоді як індукція новоутворень більшості досліджених гібридів була на рівні одного 3 батьківських сортів. 


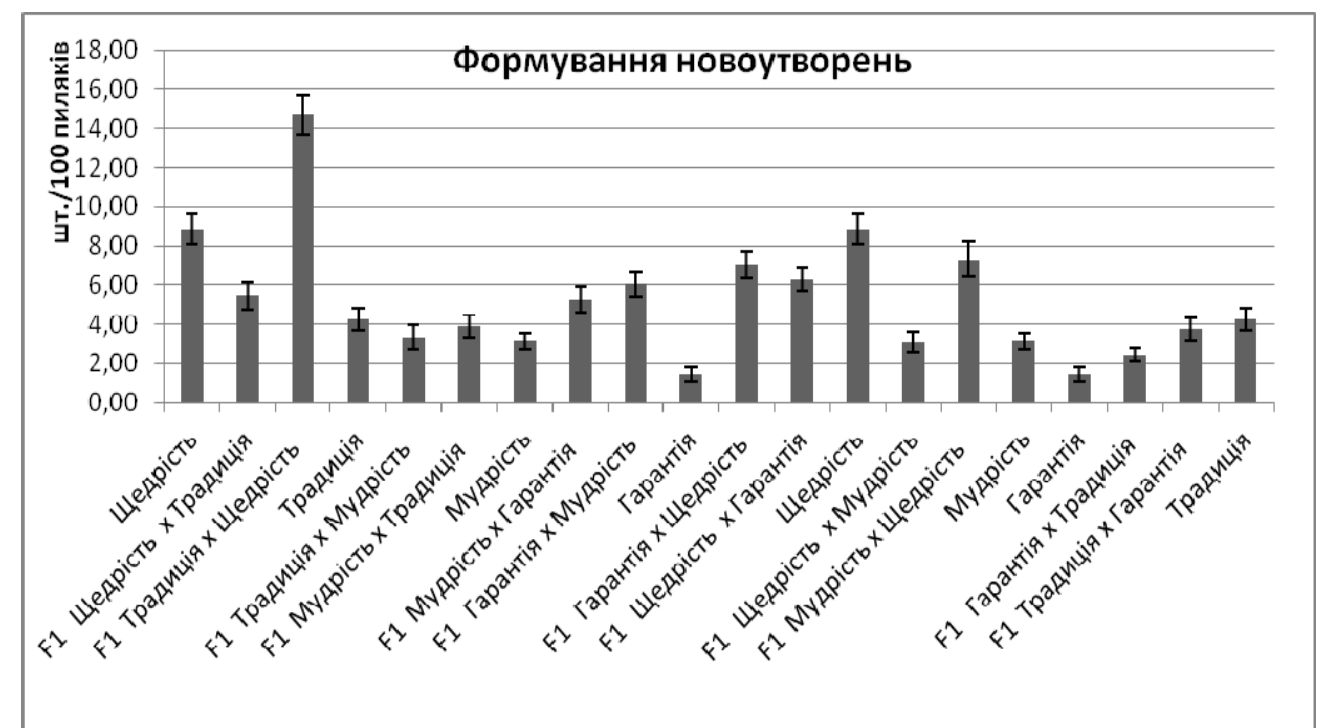

Рис. 1. Перший етап андрогенезу в культурі in vitro пиляків сортів та реципрокних гібридів $\mathrm{F}_{1}$ пшениці м'якої озимої

Притому в п'яти випадках (Щедрість х Традиція, Гарантія х Щедрість, Щедрість х Мудрість, Мудрість х Щедрість та Гарантія х Традиція) проявлявся «батьківський ефект» и лише в двох (Щедрість х Гарантія та Традиція х Гарантія) «материнський ефект». За даними літератури у пшениці відомі випадки материнського ефекту [9] та комплементарний характер успадкування здатності мікроспор до андрогенезу $[9,10]$. A W. P. Bullock, навпаки, вказує на відсутність впливу материнської цитоплазми [11]. Інші автори, так званий реципрокний ефект, відносять до генетичної адитивнодомінантної моделі взаємодії ядерних генів, та зазначають, що материнський ефект визначає індукцію ембріоїдів в культурі пиляків [12]. Отже, дане питання щодо реципрокних ефектів та ролі цитоплазматичних i ядерних генів в наслідуванні ознаки чутливості до андрогенезу in vitro пшениці потребує додаткових досліджень.

Регенераційний потенціал отриманих новоутворень виявився досить високим - в середньому третина новоутворень в подальшому формувала зелені рослини-регенеранти. Щодо наслідування цього показника, гетерозисний ефект виявлений у лише гібрида Традиція х Щедрість. Інші гібриди мали відсоток регенерації, який або достовірно не розрізнявся 3 таким у одного з батьків, або мав проміжний характер (рис. 2).

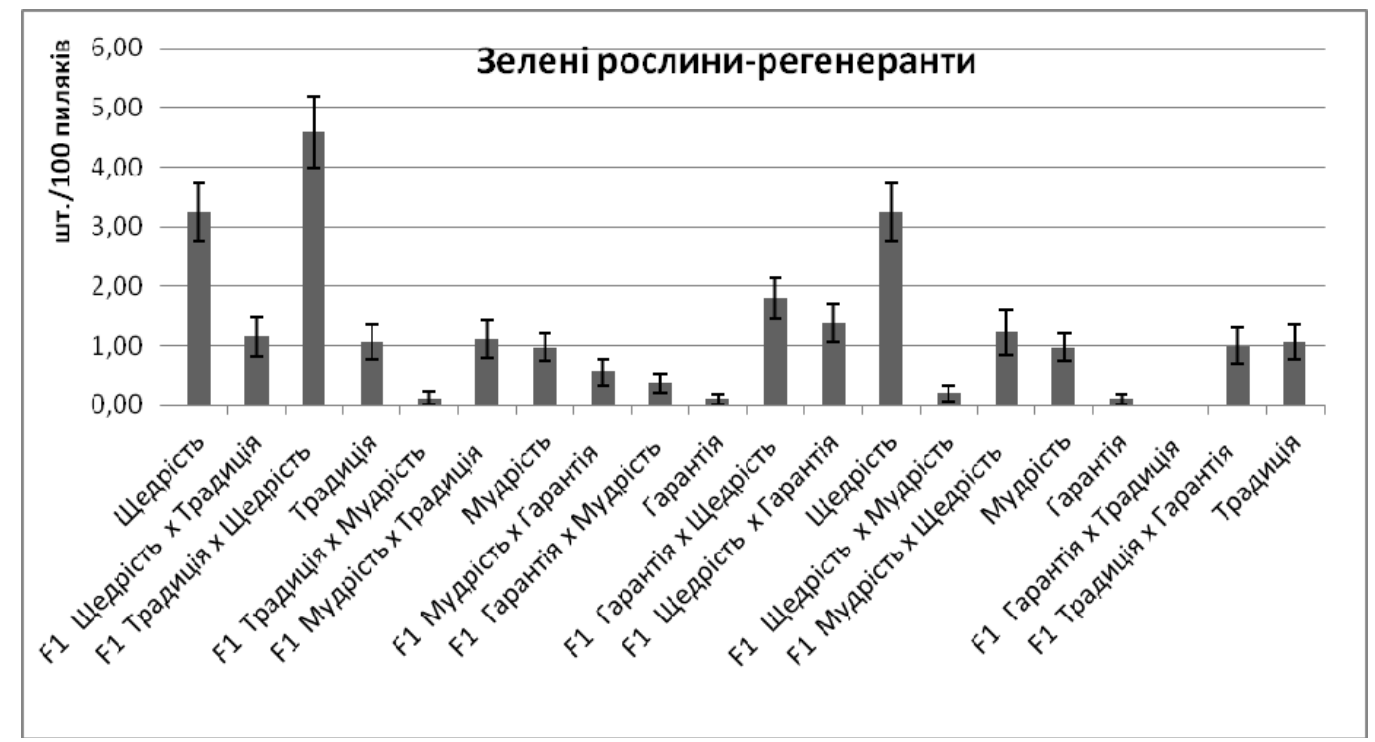

Рис. 2. Другий етап (регенерації) андрогенезу в культурі in vitro пиляків сортів та реципрокних гібридів $\mathrm{F}_{1}$ пшениці м'якої озимої

Цікавими для розкриття характеру наслідування здатності до регенерації зелених рослин в культурі in vitro пиляків м'якої пшениці є отримані результати щодо регенерації двох гібридів $\mathrm{F}_{1}-$
Традиція х Мудрість та Щедрість х Мудрість. Виявлено ефект депресії даної ознаки. Цій факт потребує уваги та подальших досліджень, однак на даному етапі ми не зможемо об'єктивно об'яснити 
отримані результати. Зрозуміло, що дана реакція в умовах культивування in vitro пов'язана 3 певною комбінацією генів від батьківських сортів, і подальші дослідження виявленого феномену повинні відбуватися на молекулярно-генетичному рівні.

Загально відомо, що для підвищення гаплопродукційної здатності різних генотипів пшениці доцільно залучати у схрещування «донори гаплопродукції» - форми пшениці, що характеризуються високим рівнем формування новоутворень в культурі ізольованих пиляків [5]. Тому, має теоретичний та практичний інтерес виявлений при схрещуванні сортів Щедрість (високі показники гаплопродукції) та Гарантія (низький відгук в культурі пиляків in vitro) позитивний вплив на ефективність андрогенезу у гібридів $\mathrm{F}_{1}$. Цей факт дозволив нам рекомендувати сорт Щедрість як потенційний «донор гаплопродукції» для введення у схрещування при виконанні селекційних програм.

\section{6. Висновки}

В культурі in vitro пиляків пшениці озимої м'якої отримано 283 зелених рослин регенерантів. За рівнем індукції новоутворень у трьох гібридів виявлено гетерозисний ефект прояву даної ознаки. У інших досліджених гібридів індукція новоутворень була на рівні одного з батьківських сортів: в п'яти випадках проявлявся «батьківський ефект» і в двох «материнський ефект». За рівнем регенерації зелених рослин виявлено гетерозисний ефект у гібрида Традиція х Щедрість та ефект депресії даної ознаки у двох гібридів $\mathrm{F}_{1}$ - Традиція х Мудрість та Щедрість х Мудрість. Інші гібриди мали відсоток регенерації, який або достовірно не розрізнявся з таким у одного 3 батьків, або мав проміжний характер.

\section{Література}

1. Ігнатова, С. О. Особливості виявлення рівня чутливості до андрогенезу різних генотипів м'якої пшениці в культурі пиляків [Текст] / С. О. Ігнатова, М. В. Жосонар, К. І. Лобанова // Фізіологія та біохімія культурних рослин. - 2010. - Т. 42, № 2 (244). - С. 107-117.

2. Корня, Т. М. Дослідження впливу генотипу на ефективність створення шляхом андрогенезу in vitro гомозиготних форм м'якої пшениці із стійкістю до Fusarium graminearum [Текст] / Т. М. Корня, Д. В. Аксельруд, О. О. Молодченкова // Фактори експериментальної еволюції організмів: збірник наукових праць. 2011. - T. 11. - C. 320-325.

3. Шестопал, О. Л. Вивчення гаплопродукційної здатності м'якої пшениці 3 пшенично-житніми транслокаціями [Текст] : VIII Міжнар. наук. конфер. / О. Л. Шестопал, І. С. Замбріборщ, М. М. Топал, М. А. Літвиненко, С. О. Ігнатова // Фактори експериментальної еволюції організмів. - Алушта, 2013. - Т. 12. - С. 326-330.

4. Rizkala, A. Response of some Egyptian and introduced wheat hybrids to androgenic process [Text] / A. Rizkala, A.-A. Attia, H. Nasseef // International Journal of Agricultural Research. - 2012. - Vol. 7, Issue 4. - P. 205-214. doi: 10.3923/ijar.2012.205.214

5. Літвиненко, М. А. Біотехнологічні методи у селекції сільськогосподарських культур [Текст] / М. А. Літвиненко // Вісник аграрної науки. - 2010. - № 6. - С. 11-14.

6. Игнатова, С. А. Клеточные технологии в растениеводстве, генетике и селекции возделываемых растений: задача, возможности, разработки систем in vitro [Текст] : монография / С. А. Игнатова. - Одесса: Астропринт, 2011. - 224 с.

7. Wang, X. The effect of potato II medium for triticale anther culture [Text] / X. Wang, H. Hu // Plant Science Letters. - 1984. - Vol. 36, Issue 3. - P. 237-239. doi: 10.1016/03044211(84)90175-5

8. Лобанова, К. І. Шляхи реалізації регенераційного потенціалу в культурі пиляків у різних генотипів озимої м'якої пшениці [Текст] / К. І. Лобанова, М.В.Жосонар, С. О. Ігнатова // Вісник Українського товариства генетиків і селекціонерів. - 2006. - Т. 4, № 1. - С. 52-57.

9. Nazan, D. Diallel analysis of anther culture response in wheat (Triticum aestivum L.) [Text] / D. Nazan // African Journal of Biotechnology. - 2008. - Vol. 7, Issue 19. P. 3419-3423.

10. Волощук, С. І. Вплив обробки зеараленоном та КФ на ефективність отримання гаплоїдів в культурі пиляків м'якої пшениці та тритикале [Текст] :VI міжн. конф. / С. І. Волощук, Г. Д. Волощук // Сучасна біотехнологія сільськогосподарських рослин та біобезпека (Геном рослин VI). - Одеса, 2010. - С. 80.

11. Bullock, W. P. Anther culture of wheat (Triticum aestivum L.) F's and Their reciprocal crosses [Text] / W. P. Bullock, P. S. Baenziger, G. W. Shaeffer, P. J. Bottino // Theoretical and Applied Genetics . - 1982. - Vol. 62, Issue 2. P. $155-159$. doi: $10.1007 / \mathrm{bf} 00293350$

12. Tabatabaei, B. E. S. Genetic analysis of androgenetic traits in wheat (Triticum aestivum L.) [Text] / B. E. S. Tabatabaei, G. Saeidi, M. R. Sabzalian // Iran. J. of biotechnology. - 2007. - Vol. 5, Issue 1. - P. 34-41.

\section{References}

1. Ignatova, S. O., Zhosonarp, M. V., Lobanova, K. I. (2010). Features identify the level of sensitivity to androgenesis in anther culture of different bread wheat genotypes. Physiology and Biochemistry of Cultivated Plants, 42 (2), 107-117.

2. Kornya, T. M., Axelrud, D. V., Molodchenkova, O. O. (2011). The influence of genotype on the efficiency of formation by androgenesis in vitro homozygous forms of bread wheat resistance to Fusarium graminearum. Factors experimental evolution of organisms: collection of scientific papers, 11, 320-325.

3. Shestopal, O. L., Zambriborshch, I. S., Topal, M. M., Lytvynenko, M. A., Ignatova, S. O. (2013). The study of haploproduction ability of bread wheat with wheat-rye translocation. VIII Intern. Science. konfer. "Factors Experimental evolution of organisms." Alushta, (12), 326-330.

4. Rizkala, A., Attia, A.-A., Nasseef, H. (2012). Response of some Egyptian and introduced wheat hybrids to androgenic process. International Journal of Agricultural Research, 7 (4), 205-214. doi: 10.3923/ijar.2012.205.214

5. Lytvynenko, M. A. (2010). Biotechnological methods in plant breeding of agricultural crops. Bulletin of Agricultural Science, 6, 11-14.

6. Ignatova, S. A. (2011). Plant Cells technology, Genetics and selection agricultural plants. Odessa: Astroprint, 224.

7. Wang, X. (1984). The effect of potato II medium for triticale anther culture. Plant Science Letters, 36 (3), 237-239. doi: 10.1016/0304-4211(84)90175-5

8. Lobanova, K. I., Zhosonarp, M. V., Ignatova, S. O. (2006). Ways of realization potential of regeneration in anther culture different genotypes of winter wheat. Bulletin of the Ukrainian Society of Geneticists and Breeders, 4 (1), 52-57.

9. Nazan, D. (2008) Diallel analysis of anther culture response in wheat (Triticum aestivum L.). African Journal of Biotechnology, 7 (19), 3419-3423. 
10. Voloshchuk, S. I., Voloshchuk, G. D. (2010). Effect of zearalenone treatment of $\mathrm{CF}$ and the efficiency of obtaining haplodes in anther culture of soft wheat and triticale. Modern biotechnology and biosafety of crop plants (Plant Genome VI) : VI International Conference, Odessa, 80.

11. Bullock, W. P., Baenziger, P. S., Shaeffer, G. W., Bottino, P. J. (1982). Anther culture of wheat (Triticum aestivum L.) $\mathrm{F}_{1}$ 's and Their reciprocal crosses.
Theoretical and Applied Genetics , 62 (2), 155-159. doi: $10.1007 / \mathrm{bf00293350}$

12. Tabatabaei, B. E. S., Saeidi, Gh., Sabzalian, M. R. (2007). Genetic analysis of androgenetic traits in wheat (Triticum aestivum L.). Iran. J. of biotechnology, 5(1), 34-41.

Рекомендовано до публікаиії д-р біол. наук Ігнатова С. О. Дата надходження рукопису 17.11.2014

Замбріборщ Ірина Сергіївна, старший науковий співробітник, кандидат біологічних наук, Лабораторія культури тканин, Селекційно-генетичний інститут Національного центру насіннєзнавства та сортовивчення, Овідіопольська дор., 3. м. Одеса, Україна, 65036

E-mail: izambriborsh@gmail.com

Шестопал Оксана Леонідівна, старший науковий співробітник, кандидат біологічних наук, Лабораторія культури тканин, Селекційно-генетичний інститут Національного центру насіннєзнавства та сортовивчення, Овідіопольська дор., 3. м. Одеса, Україна, 65036

E-mail: oksana shestopal@mail.ru

\section{УДК 579.62}

DOI: $10.15587 / 2313-8416.2014 .32023$

\section{ДОСЛІДЖЕННЯ ПРОБІОТИЧНИХ ВЛАСТИВОСТЕЙ ШТАМІВ Bacillus sp. 1.1. та B. amyloliquefaciens УКМ В-5113}

\section{С. О. Мілян, М. А. Хархота, О. О. Нечипуренко}

Проведено дослідження пробіотичних властивостей, виділенних з навколишнього середовища итамів Bacillus sp. 1.1. ma B. amyloliquefaciens УКМ B-5113. Встановлено їх морфологічні та фізіолого-біохімічні ознаки, досліджено та встановлено високу та середню антагоністичну активність щзодо музейних та актуальних итамів умовно патогенних мікроорганізмів. Показана стійкість до низьких та високих значень рН та різних концентрачій жовчних кислот

Ключові слова: бацилярні пробіотики, антагоністичні активність бацил, кормові пробіотики, вплив жовчі на бацили, атибіотики

It is conducted the research of probiotic properties discharged from the environment Bacillus sp. 1.1. and B. amyloliquefaciens UKM B-5113 strains. It is determined their morphological and physiological and biochemical characteristics, investigated and found high and average antagonistic activity against actual museum and opportunistic strains of microorganisms. It is shown a resistance to low and high $\mathrm{pH}$ values and different concentrations of bile acids

Keywords: bacillus probiotics, bacillus antagonistic activity, feed probiotics, bacillus react to bile, antibiotics

\section{1. Вступ}

На сьогоднішній день значного поширення набули шлунково-кишкові розлади дисбактеріозного типу, вони викликають проблеми не лише у людей, а й у сільськогосподарських тварин. За наявності шлунково-кишкових інфекцій в сільськогосподарських тварин погіршується їх самопочуття та зменшується продуктивність, можлива навіть їх загибель, що призводить до негативних наслідків для усього господарства. Часто для лікування шлунковокишкових захворювань застосовують антибіотичні та пробіотичні препарати.

Принцип дії антибіотичних речовин полягає у їх бактеріостатичній чи бактерицидній дії на чутливі мікроорганізми [1, 2]. Незалежно від спектру дії антибіотика його використання може призводити до загибелі не лише шкідливої, а значної кількості корисної мікрофлори. Зникнення корисної мікро- флори призводить до ряду негативних наслідків: збільшення ризику повторного інфікування патогенною мікрофлорою, яка надходить разом із їжею; сповільнення природних процесів біодеградації компонентів спожитої їжі, зниження їх енергетичної цінності за рахунок неповного розкладання та всмоктування організмом. Зменшення кількості споживаних речовин призводить до зменшення кількості енергіï, яку отримує організм, що призводить до зниження його фізичної та розумової активності.

Аспектом, який відіграє велику роль у використанні антибіотичних речовин $є$ виникнення резистентності у патогенних мікроорганізмів до цих антибіотиків [2], що змушує людей синтезувати нові антибіотики, або циклічно змінювати їх для запобігання неефективного використання антибіотиків до яких розвинулася резистентність.

Використання антибіотичних препаратів у 